\title{
The Development of the Spirituality of a Technical University's Lecturer in an Advanced Training System
}

\author{
Svetlana A. Bezklubaya* \\ bezkluba@email.com \\ https://orcid.org/0000-0001-5713-9044
}

https://doi.org/10.31192/np.18.3.6

UDK / UDC: [62:37]:177.72

$37: 2-188$

Izvorni znanstveni rad / Original scientific paper Primljeno / Received: 24. svibnja 2020. / May 24, 2020 Prihvaćeno / Accepted: 24. srpnja 2020. / Jul 24, 2020

The problem considered in the article is relevant for a post-industrial society, which sees a guarantee of self-preservation in the upbringing of professionally competent and highly spiritual technical specialists. The process of humanitarization of advanced training programs ensures the growth of spirituality in the educational environment of a technical university for faculty members. The development of the educator's spirituality is a transcendence of the alienation of the technical from morality in education. The purpose of the study: to determine how to develop the spirituality of an educator in an advanced training system. Research method: culturosophical, allows us to consider spirituality as the development of the highest value senses of culture. The theoretical part of the study in relation to a technical university considers: the multi-dimensionality understanding of spirituality; humanization as the essence of the manifestation of 'human spirit' in education, and humanitarization as a way of its implementation; humanitarization as a factor in the development of spirituality and a strategy for the formation of an understanding of the moral meaning of the engineering profession; humanitarian environment as the basis for the formation of spiritual, moral and cultural qualities of a person; dialogue as an imperative of the development of spirituality. The practical part of the study describes the results of the introduction by the author of a new program with a humanitarian component at the Center for Advanced Studies of Scientific and Pedagogical Workers of the Moscow Aviation Institute (National Research University):

\footnotetext{
* Svetlana A. Bezklubaya, PhD, Assoc. Prof., National Research University, Institute of Engineering, Economics and Humanities at Moscow Aviation Institute, Department of Philosophy, A-80, ГСП-3, 4 Volokolamskoe shosse, RU-125993 Moscow, Russia.
} 
humanization and humanitarization create a highly spiritual environment; the technocratic narrowness of engineering education is overcome by interdisciplinarity; the connection of all subsystems of the spiritual sphere of society is revealed. The complexity of realization the program is due to the difference in thinking styles (technical versus humanitarian) and the psychology of perception of unaccustomed information. Overcoming the antinomy of knowledge leads to dialogue and the development of the spirit.

Key words: advanced training system, creative nature of education, humanitarian environment, humanization and humanitarization of education, interdisciplinarity, spirituality, technocratism.

\section{Introduction}

The activity of modern man violates the techno-humanitarian balance of culture, which leads to the loss of significancy of religious and secular values. The utilitarian problems of high-tech life become more important than the improvement of spirituality. The Russian religious philosopher Nikolai Berdyaev also predicted the death of the spirit in a technicized society:

»The machine wants a person to take its image and likeness. But man is the image and likeness of God and cannot become the image and likeness of a machine without ceasing to exist ${ }^{1}{ }^{1}$

A person who understands any technical task both rationally and in a valuedriven way can prevent a spiritual catastrophe. To train a highly moral and responsible specialist, the technocratic model of education is not suitable. The technical style of thinking critically perceives the organics of spirituality. The humanitarization of the continuing education system of the faculty members allows overcoming the technocratism of higher education. Humanitarization foregrounds the problem of the development of the teacher's spirituality as a creative act of transforming narrow professional knowledge into a personal value resource. A general theoretical analysis of the concept of "spirituality» is a study of the value content of consciousness, the life goals of the individual, problems of spirit in the context of culture. The study of spirituality led to the appearance of two barely overlapping concepts, religious and secular, each with its own rhetoric and emotional content. We are interested in the practical side of solving this issue: the humanitarization of the advanced training system of lecturers in a technical university as a factor in the development of the spirituality of the teaching staff. The methodological basis of the study was the culturosophical approach, the use of which allowed us to consider

\footnotetext{
${ }^{1}$ Nikolai BERDYAEV, Man and Machine [Chelovek I mashina], Voprosy filosofii, 2 (1989), 151-
} 157. 
the spiritual experience of humankind as a value-driven part of the world of culture. The spiritual manifests itself through the realization of goodness and requires from a person the humanitarization of the natural, social and personal environments. The description of the author's experience in introducing a new program with a humanitarian component at the Center for Advanced Studies of Scientific and Pedagogical Workers of the Moscow Aviation Institute (National Research University) affirms ways to transcend the alienation of the technical from the spiritual.

\section{Humanitarization of education and the development of spirituality}

The modernization of higher education in Russia is in line with the global trend of improving the effectiveness of education, which began in the 1980s and was called by P. Sahlberg the Global Educational Reform Movement (GERM). Sahlberg's ideas about the main components for schooling (standardization of curricula; reduction of innovative teaching strategies; use of business management methods in educational management; external testing of students as quality control of knowledge; strict reporting mechanisms based on rewards and sanctions for pupils, teachers and schools) over time have been extrapolated to university education as a technocratic pattern. ${ }^{2}$ Today, principles of spirituality in university education are being supplanted by harsh educational technologies. Humanitarization as a strategy of forming an understanding of the moral meaning of the engineering profession allows for avoiding the extinction of the spirit.

Different branches of knowledge in three directions theoretically investigate the phenomenon of spirituality: soulful manifestations of a person, the theological paradigm, cultural and historical standard of development. There is no single scientific definition of spirituality; this concept is interpreted from different points of view: the primacy of ideas over matter by Plato ${ }^{3}$; the cosmic evolution by V. Vernadsky ; a spiritual pattern by G. W. F. Hegel ${ }^{5}$; an identity with consciousness by K. Marx ${ }^{6}$; the spiritual production by N. Berdyaev ${ }^{7}$; the

2 P. SAHLBERG, Education Reform for Raising Economic Competitiveness, Journal of Educational Change, 7 (2006) 4, 259-287.

${ }^{3}$ PLATON. Sobranie sochineniy v 4 tomah [Works in 4 volumes], Moscow, Mysl, 1994, V. 3.

4 V. I. VERNADSKY, Biosfera (1926). Iabrannye Trudy po biohimii [Biosphera (1926). Selected Works on Biochemistry], Moscow, Mysl, 1967.

${ }^{5}$ G. W. F. HEGEL, The Phenomenology of Spirit. Translated by Peter Fuss and John Dobbins, University of Notre Dame Press, Indiana, 2019.

${ }^{6}$ K. MARX, Theses on Feuerbach (1845), Marx Engels Selected Works, (MESW), Moscow, Progress Publishers, 1969, V. 1, 13-15.

${ }^{7}$ N. A. BERDYAEV, Filosofia svobodnogo duha [Freedom and Spirit], Moscow, Respublika, 1994. 
basics of the formation of the psyche and human behaviour by A. Thomasson; the humanistic psychology as the formation of the integrity of the personality in the process of its creative self-determination by C. Rogers ${ }^{9}$; the dialogue concepts by M. Bakhtin ${ }^{10}$; a method of updating metaphysics in Catholic theology by K. Rahner ${ }^{11}$; and overcoming metaphysics in Protestant thought by $\mathrm{K}$. Barth ${ }^{12}$. Thus, the content of the concept of spirituality is debatable.

It is difficult to express the essence of spirituality in rational terms. As $\mathrm{N}$. Berdyaev wrote, one can only catch signs of the spirit: freedom, meaning, creative activity, mercy, appeal to the divine world, and striving for perfection..$^{13}$

»The spiritual must be contrasted with the natural and the everyday. Spiritual overcoming of humdrums individually. Everyone can diversify their day-to-day routine, but not make their lives spiritual. Spiritualization involves not just copying high cultural samples, but the work that will elevate a person over vanity will ennoble everyday life. The antithesis of spirituality is cynicism, contempt for people and life values «. ${ }^{14}$

The imperative of man's spiritual development is the movement of values from metaphysical to transcendental. M. Bakhtin argued being is not formed by metaphysics, but by the components of the human spirit: dialogue, responsibility, guilt, confession, activity, repentance. Therefore, the dialogue of ideas in the spiritual sphere is »incomplete, it will continue as long as there are thinking and searching people. Its end would be tantamount to the death of mankind and humanness «. ${ }^{15}$

In Christian anthropology, spirituality is the striving for the image of God, realized through the unity of the body, soul and spirit. Luke of Simferopol (Voyno-Yasenetsky) noted: »The spirit and soul of a person are inseparably united into a single entity: but we can see different degrees of spirituality in people ${ }^{16}{ }^{16}$ The development of spirituality is the way of human climbing and

${ }^{8}$ Amie L. THOMASSON First-Person Knowledge in Phenomenology in Phenomenology and Philosophy of Mind Edited by David Woodruff Smith and Amie L. Thomasson, Oxford, Oxford Scholarship Online, 2010.

9 Carl R. ROGERS On becoming a person. A therapist's view of psychotherapy, NY, Houghton Mifflin Harcourt, 1995.

${ }^{10}$ M. M. BAKHTIN, O bolshom vremeni [About big time] in Bakhtinologia: Issledovamiya, perevody, publikatsii [Bakhtinology: Researches, translates, publications], Sankt-Petersburg, Aleteya, 1995, 7-18.

${ }^{11}$ Karl RAHNER, Hörer des Wortes. Zur Grundlegung einer Religionsphilosophie, München, 1963, 21.

${ }^{12}$ Karl BARTH, Protestant Theology in the Nineteenth Century, Wm B. Eerdmans Publishing Co., Cambridge, 2002.

${ }^{13}$ Berdyaev, Filosofia svobodnogo duha...

${ }^{14}$ S. A. BEZKLUBAYA, Filosofia v tehnicheskom vuze kak sposob formirovania duhovnosti studencheskoi molodezhi [Philosophy in Technical University like a Way to Form the Spirituality of Student Youth], Human Capital, 3 (2019) 88-99.

${ }^{15}$ Bakhtin, O bolshom vremeni..., 7.

${ }^{16}$ Svyatitel LUKA (VOYNO-YASENETSKY), Dukh, dusha i telo [Spirit, Soul and Body], Moscow, Obraz, 2009, 74. 
approaching to God. The attribute of spirituality is faith and the willingness of a person to change. Thomas Aquinas connects the faith (fides) with the need for spiritual self-improvement: the implementation of a moral choice (between good and evil), and manifestations of free will, which is correlated with reason and divine grace. The goal of man is the achievement of an absolute good, and the possession of such a good is happiness. ${ }^{17}$

Thus, spirituality is a complex substantive and phenomenological formation, where religious motives and science are contradictorily connected. Any interpretation of spirituality captures the manifestation of the highest beauty and harmony of all personality traits, the unity of intellect and virtue. The degree of presence of spirituality in human life is determined by the intensity of the processes: creativity, self-knowledge, moral self-improvement, and the creation of ontological schemes and an ideal plan of activity.

Over time, the conceptual ideas of spirituality have combined with the problems of training and education. W. Dilthey introduced the method of Geisteswissenschaft (literally, »science of the mind" or 'spiritual knowledge'), the essence of which was to study the results of the creative activity of the spirit of the folk through a consistent description, experience and understanding, first of all, of works of arts. Dilthey's method is interdisciplinary, combining the principles of psychology, philosophy, literary criticism and natural sciences. A supporter of this method, E. Spranger, substantiated the essence of geisteswissenschaftliche Psychologie (literally, »comprehending psychology«), the aim of which was to comprehend the common values of life. »These values«, noted Spranger, »originated in historical life, which in their sense and significance go beyond the limits of individual life, we call spirit, spiritual life, or objective culture ${ }^{18}$

Spirituality as the reclamation of higher-value cultural meanings is the basis for the development of the lecturer's spirituality, the formation of his personality as integrative (combining humanistic concepts of a professional picture of the world with the individual being of the spirit) and reflexive (reassessment of beliefs and value relationships). V. Fedotova points out the primacy of the value content of consciousness in the cultural spirituality and identifies four types of spirituality: aestheticism (the prevailing value is Beauty), ethism is (Good), theoretism (Truth), religiosity (the divine will is considered the source of moral standards). ${ }^{19}$ She defines the $»$ theoretism $"$ of the dominant scientific intelligentsia and leaders in the sphere of governance. The main features of »theoretism«

\footnotetext{
${ }^{17}$ St. THOMAS AQUINAS, Summa Theologica Part I (Prima Pars) Translated by Fathers of the English Dominican Province, NY, 1920.

${ }^{18}$ E. SPRANGER, Dva vida psihologii [Two Types of Psychology] in Textbook on the History of Psychology, Moscow. Moscow University, 1980, 295.

${ }^{19}$ V. G. FEDOTOVA, Prakticheskoe I duhovnoe osvoenie deystvitelnosti [Practical and spiritual development of reality], Moscow, Nauka, 1991, 99.
} 
are multilateral knowledge, the development of all types of thinking, readiness to learn and create new things, forecasting and modelling. ${ }^{20}$

Technocratism and scientism weaken the value of interpersonal relationships and distort spirituality. Therefore, the educator of a technical university must be aware of the teaching process as a spiritual experiment in creation of personality. The constant desire of the educator to develop his own spirituality is the push for the undeterred qualitative improvement of the spirit of the student. The spiritual development of the educator is the basis of his successful dialogue with the student, acceptance of his uniqueness as the uniqueness of the »other «. Spirituality allows the best aspects of the educator's personality to manifest itself openly:

»in the fascination for the subject, in the desire to give the student sincerely experience different feelings - surprise, distrust, scepticism, dissatisfaction, freedom, embarrassment, courage, pride; in an effort to empathize with him, that is, to show empathy. In these conditions, the lecturer's pedagogical activity is an example of creative competition, and a student against this background can actively build up his personal and professional appearance ${ }^{21}{ }^{21}$

V. Slobodchikov and E. Isaev determine the steps of spiritual growth depending on the appearance of the subjective spirit: personal (integral), individual (single-unique) and universal (generic) being of human. They are the stages of becoming a spiritual being. The basis of this process is the improvement and refinement of the mechanisms of spiritual life of a person, his subjectivity. ${ }^{22}$ The development of human subjectivity because of the improvement of his personal qualities is a concept of a humanitarian paradigm. It is obvious that the humanitarization of educator development programs will allow them to move to a higher level in the development of spirituality and thereby overcome the alienation of the technical from the spiritual in university education.

Humanitarization as the formation of humanitarian thinking and knowledge is based on humanization - the preservation of a system of values that elevate the human personality (freedom, social justice, dignity, tolerance, mercy). Humanization is the essence of education, and humanitarization is a way of revealing it. Humanitarization is a way of creating a technical university's special environment in which culture's humanistic ideas about the spirit are concentrated.

\footnotetext{
${ }^{20}$ Ibid., 57-59.

${ }^{21}$ S. A. BEZKLUBAYA Gumanitarnaya sreda tehnicheskogo vuza kak osnova formirovaniya konkurentosposobnogo spetsialista [The Humanitarian Environment of a Technical University as the Basis for the Formation of a Competitive Specialist], Human Capital, 5 (2018), 56-68.

${ }^{22}$ V. I. SLOBODCHENKOV, E. I. ISAEV, Psihologia cheloveka. Osnovy psihologicheskoi antropologii. Vvedenie v psihologiyu subyektivnosti [Human Psychology. Fundamentals of Psychological Anthropology. Introduction to the Psychology of Subjectivity], Moscow, ShkolaPress, 1995.
} 
Modern scientific ideas about the humanitarian environment are didactic. Western European pedagogy's reformers viewed the educational space from the perspectives of:

- The superiority of diverse experience over systematized knowledge ('instrumental pedagogy') by J. Dewey ${ }^{23}$;

- The importance of moral and civic education by G. Kerschensteiner ${ }^{24}$;

- Broad fundamental education by E. Durkheim ${ }^{25}$;

- Humanism of the individual and society by A. N. Whitehead ${ }^{26}$;

- Preparation for life and participation in it by Alain ${ }^{27}$;

- Creation of better conditions for the intellectual development of students by P. Natorp and his theory of »independent discoveries« ${ }^{28}$

In the Russian scientific tradition, the humanitarian environment more often means:

"firstly, the university's space, which a certain pedagogical system creates in order to establish the spiritual, moral and cultural qualities of the student's personality; and secondly, a set of psychological, pedagogical, professional, organizational and moral-legal measures aimed at intensifying the educational process $\ll .{ }^{29}$

The concept of 'humanitarian environment' is associated with the concept of »mentality« as a common spirituality of society, a universal picture of the world and cultural tradition. The mentality is always humanistically (that is, person) oriented - which means it is a creative phenomenon both in relation to the individual person and society as a whole.

Obviously, the humanitarian environment of a technical university is focused on the personality and its creative development. In such an educational space, the traditional roles of educator and student are changing. The teacher does not remain

${ }^{23}$ J. DEWEY, Opyt i obrazovanie [Experience and Education]. in Demokratia I obrazovanie [Democracy and Education], Moscow, Pedagogika-press, 2000.

${ }^{24}$ G. KERSCHENSTEINER, O vospitanii grazhdanstvennocti [About Civic Education]. Trans. E.

N. Zhuravskaya, Petrograd, Publishing house of the newspaper 'School and Life', 1917.

${ }^{25}$ E. DURKHEIM, Sociologia. Ee predmet, metod, prednaznachenie [Sociology. Its Object, Method, Purpose], Moscow, Kanon, 1995.

${ }^{26}$ A. N. WHITEHEAD. Izbrannye raboty po filosofii [Selected Works on Philosophy], Moscow, Progress, 1990.

${ }^{27}$ ALAIN, Suzdeniya [Judgments] Moscow, Respublika, 2000.

${ }^{28}$ P. NATORP, Obshchaya pedagogika [General Pedagogy], Moscow, 1910.

${ }^{29}$ O. A. KOLONITSKAYA, Gumanitarnaya sreda - odin iz sposobov reshenia problem vysshego professionalnogo obrazovania [The Humanitarian Environment is One of the Ways to Solve Problems of Higher Professional Education], Young Scientist, 5 (2012), 431-435. 
»only a systematizer of knowledge, curator of the work of students, a key figure in the teaching of ideas and laws. It is usual, university teacher gives and forms only those skills that can be easily tested, and the student only takes them. That is, the educator accompanies the acquisition by students of the competencies necessary for successful activities and tracks the experience of their manifestation. For the student's emerging competing personality, this is not enough. In this case, you need not just 'building competencies', but pedagogical creativity. The professionalism of a university teacher can manifest itself in the ability not only to design the educational process, but also to creatively implement it, continuously maintaining feedback with students, and carrying out an adequate correction of knowledge acquisition. Exactly the educator who creates conditions in a unique personal relationship with the student that make him study not formally and boringly, but with interest «. ${ }^{30}$

The humanitarian environment, bringing together cognitive goals and universal values, provides an opportunity for both the educator and student to grow spiritually. The humanitarian component of the advanced training system of a technical university allows the teacher to understand that only if he fully possesses spiritual competences, will he be able to form them in a student. Moreover, these competencies are not limited only to narrow-professional knowledge.

Therefore, the technical style of thinking can change and enrich spirituality as a creative approach to life and a conscious choice of the highest values of culture. The moral component of the processes of humanization and humanitarization increases the share of human content in technical educational structures. Humanitarization as a way of embodying humanistic ideals and as a value concept is the most important factor in the development of an educator's spirituality. Humanitarization is the basis for creative understanding of the unity of cognitive, value and behavioural orientations by him. The humanitarian environment of the university enhances the spiritual content of the studying, training and teaching activities of teachers, and allows the understanding that every professional task has not only a rational solution, but also a moral component. The humanitarization of the advanced training system turns it for the educator into a 'creative laboratory' of the spirit.

\section{Practical experience in implementing a program for the development of spirituality}

With the aim of humanitarization of the activity and developing the spirituality of the teaching staff, the authoress of the article developed and implemented the program 'The Impact of the Humanitarian Educational Environ-

\footnotetext{
${ }^{30}$ Bezklubaya, Gumanitarnaya sreda..., 63.
} 
ment on the Quality of Engineering and Technical Education at a University' in the Advanced Training System of the Moscow Aviation Institute.

When constructing the program, the shortcomings of the Russian advanced training system were taken into account (its lack of connection with the modern educational process and the competencies of the professional and pedagogical culture; focus on knowledge only) and the forms of its updating were studied (joint classes of teachers and students; a polylogue on issues in higher education with representatives of the academic community of educators, university management, and undergraduate and postgraduate students; a combination of traditional forms of advanced training for distance learning with the personal side of the developmental and the educational process; modelling sustainable motivation of educators to continuous professional and general cultural development). ${ }^{31}$

The goal of the program is to improve the humanitarian competencies of teachers of technical and general educational disciplines. The program implements the processes of humanization and humanitarization in a practical way, creating a high-spiritual environment that allows the educator to think freely, and therefore the student to learn creatively.

The material world cannot develop without the spiritual. Technique divorced from morality is transformed from a creative force to a destructive one. It is no coincidence that in the system of modern engineering education, the emphasis is on techno-humanistic synthesis: combining the technocratic STEM-paradigm (S-science; T-technology; E-engineering; M-mathematics) with ideas of social responsibility (as in the European program of 2004-2014 to promote ideas of the sustainable development and social assessment of technology in technical universities) ${ }^{32}$.

In order to overcome the technocratic narrowness of engineering education, the program is based on: interdisciplinarity as a methodological basis for effective cooperation between humanitarian and engineering departments; prevention of degradation of humanitarian disciplines in a technical university and loss of understanding of their ethical significance; the role of philosophical knowledge as a historically unified methodological basis, bringing together the ideas about the spirit of all humanities; integration of philosophical knowledge in technical and natural sciences. For instance, philosophical aspects are present in the problems of: quantum mechanics during the transition from sub-

\footnotetext{
${ }^{31}$ T. E. ISAEVA, Neobhodimost' modernizatsii sistemy povysheniya kvalifikatsii prepodavateley tehnicheskih universitetov [The Need to Modernize the Advanced Training System for Teachers of Technical Universities] (2015), http://e-koncept.ru/2015/85340.htm (2020).

${ }^{32}$ V. N. ZHELEZNIAK, E. V. SEREDKINA, Engineering ethics in a technical university: challenges and expectations. (2017), https://www.researchgate.net/profile/Elena_Seredkina/ publication/318444552_Engineering_ethics_in_a_technical_university_challenges_and_expectations/links/5aa8b942aca2726f41b175ef/Engineering-ethics-in-a-technical-universitychallenges-and-expectations.pdf (2020).
} 
atomic systems to macroscopic ones (Schrödinger's cat ${ }^{33}$ ); consciousness and artificial intelligence (the 'Chinese room' by J. Searle ${ }^{34}$ ); 'Mill' by G. W. Leibniz ${ }^{35}$; cognitivistics and neuroethics (the 'trolley problem' by F. Foot ${ }^{36}$ ); the establishment of computer communication algorithms by analogy with linguistic ones ('paper machine' and 'test' by A. Turing ${ }^{37}$ ); the refutation of functionalism in mentality ('Chinese nation' by N. Block ${ }^{38}$ ).

As a result of the humanitarization and humanization of the advanced training program a connection is revealed between all subsystems of the spiritual sphere of society - culture, science, religion, morality, ideology, art, law.

Therefore, the subject matter of the program reflects the problems of both engineering activity and the engineer himself as an object and subject of sociocultural relations.

Educators study issues related to features of the:

- Existence of technogenic civilization;

- Modern ideas about the unity of man, society, culture and nature;

- Interaction of different branches of scientific knowledge;

- Coexistence of science and morality;

- Anthropological measurement of technology;

- Technical and informative upgrade of culture;

- Modernization of intellectual resources;

- Modern strategies for engineering education;

- Humanitarization of the delivery of the program of study in a technical university;

- Personality oriented education;

- National cultural relations;

- Training and development of a competitive specialist;

- Humanitarian environment of a technical university;

${ }^{33}$ E. SCHRÖDINGER, Die gegenwärtige Situation in der Quantenmechanik [Teil 1] in Die Naturwissenschaften, 1935, 29 Novembers (Bd. 23, H. 48), 807-812.

${ }^{34}$ J. SEARLE, Minds, brains, and programs in Behavioral and brain sciences, 3 (1980), V. 3, 417424.

${ }^{35}$ G.-W. LEIBNIZ, Monadologiya, 1710 in Sochineniya v chetyreh tomah / Leibniz G.-W., Moscow, Mysl, V. I, 413-429.

${ }^{36}$ Philippa FOOT, The Problem of Abortion and the Doctrine of the Double Effect in Virtues and Vices (Oxford: Basil Blackwell, 1978) (originally appeared in the Oxford Review, Number 5, 1967.

${ }^{37}$ A. M. TURING, Vychislitel'nye mashiny i razum [Computing Machinery and Intelligence] in Douglas R. Hofshtader, Daniel C. Dennet, Glaz razuma [The Mind's I], Samara, Bahrah-M, 2003, 47-59.

${ }^{38} \mathrm{~N}$. BLOCK, Searle's arguments against cognitive science in Views into the Chinese room: New essays on Searle and artificial intelligence, 2002, 70-79. 
- Relationship of spiritual and moral standards and professional development of the future engineer;

- Ethics of productive business communication;

- Modern information and communication technologies in the delivery of the program of study and personal development;

- Competency-oriented approach to the delivery of the program of study in a technical university.

On successfully completing the program, participants should be aware of:

- The state and development paths of modern engineering education;

- Sociocultural problems of technogenic and post-industrial society;

- Features of human interaction, culture, information;

- The role and place of the humanitarian environment in higher engineering education;

- The connection of the spiritual and moral standards of the engineer and his professionalism;

- The potential of interactive information and communication technologies in the training space of higher education.

They should have the skills to:

- Better adapt to the modern sociocultural environment;

- Create an environment to solve the problems of spiritual culture;

- To identify in the process of teaching one's subject an ethical component that contributes to the formation of students' responsibility for decisions and their consequences;

- Establish a person-to-person relationship with students as the most pedagogically appropriate;

- Apply modern educational technology, including information technology, in the delivery of the program of studies.

They may possess the:

- Methodology for creating such conditions for classes in which the structure and teaching methods would reflect the processes occurring at the level of culture as a whole;

- Understanding of the need for a humanistic orientation in teaching subjects, the role of humanitarian knowledge as the most important condition for students' evaluative and intellectual activity;

- Information technology as a tool for professional development. 
It proved to be difficult to put into practice the provisions of the program: a 'technical' person blocks everything in his mind (thoughts, judgments, doubts, morality) that threatens technical reality. The technocrat does not want to know that the weakly expressed rationality of humanitarian knowledge is offset by interdisciplinarity and the emergence of modern scientific disciplines: philosophy of space and cosmonautics, biological ethics, social economics, cultural studies, the history of science and technology, philosophy of technologies, mathematical methods in sports, modelling sports activities etc.

In order to join the fullness of the spiritual culture, a highly- motivated teaching staff is needed for self-education and self-improvement - not in the fields of natural science and technology, but humanitarian knowledge (cultural, philosophical, psychological, pedagogical, social, philological). Here, for many participants of the course - technical specialists - insurmountable obstacles arise due to a lack of understanding of the reasons:

- Confrontations between humanitarian and technocratic cultural patterns that form dissimilar worldview models, thinking styles, intellectual products and strategies of social practices;

- The internal integrity of the entire cognitive process;

- Historical consistency of scientific knowledge;

- The unquestioned authority of the values of technicism in the mass consciousness.

There are also the psychological difficulties of perceiving new and unusual information.

However, the constant interest among participants for such topics as: the anthropological foundations of values, the change of value priorities in culture and society, the phenomenon of global culture and its practical level - mass culture; the genesis of the spiritual culture of Russian society and the formation of ideas related to Good (collegiality, unity, industriousness) and their consolidation in fundamental moral values (collectivism, patriotism, internationalism, education). The questions of correlation between secular and religious, science and religion, spirituality and spiritless, and ethical positions in codes of engineering professions always cause discussion. The creative and destructive roles of information technology in education in general, and in higher technical education in particular, are closely studied as well.

So, the advanced training program, in which there is a humanitarian component, teaches the educator to create an environment for the development of spirituality in different departments:

- Humanitarian - analysing and comparing the events of the past and present, reaching the fullness of knowledge about a person, understanding the harmony of physical and spiritual, professional and general cul- 
ture, the principles of the formation of such values as health and competitiveness;

- Science and technology - focusing on the practical issues of life; including criteria for moral, psychological, environmental and aesthetic functionality in assessing the quality of the innovative aspect of technical objects in order to turn engineering and technology into human allies.

Exact sciences are a monologous form of knowledge; the intellect contemplates a thing and speaks out about it. The humanities, on the contrary, are dialogical as knowledge of a person with his specific features. In becoming elements of one's system of personal values, humanitarian knowledge affects the formation of the spiritual foundations of the individual. The entry of the values of humanitarian culture into the content of technical and natural disciplines involves the educator in the process of actively comprehending the spiritual level of culture. Overcoming the antinomy of knowledge leads to dialogue and the development of the spirit.

\section{Conclusion}

Humanitarization of technical university lecturers' advanced training programs is a way to transfer humanistic values to future engineers who must have both Hard Skills (professional competencies) and Soft Skills (personal qualities). The priority of spiritual-moral and socio-cultural components, being applied through the teaching to the entire educational field, eliminates narrowly-professional approaches within it.

The spiritual development of the teacher is a reflection of the life attitudes and ideals of effective humanism, dialogical cooperation, empathy, tolerance, and freedom of creativity. Integrating the value orientations of humanitarian and technical disciplines harmonizes the spiritual growth trajectory of the educator's personality, and through him the student. 


\section{Svetlana A. Bezklubaya* \\ Razvitak duhovnosti predavača sustava naprednog treninga na tehničkom sveučilištu}

\section{Sažetak}

Problem koji se razmatra u članku važan je za postindustrijsko društvo koje želi osigurati odgoj profesionalno mjerodavnih i izrazito duhovnih tehničkih stručnjaka (specijalista). Proces humanitarizacije programa naprednog treninga teži porastu duhovnosti fakultetskog osoblja u odgojnoj okolini (okružju, sredini) nekoga tehničkog sveučilišta. Razvitkom odgojiteljeve duhovnosti, u odgoju se prevladava tehničko otuđenje u odnosu na moral. Cilj proučavanja: odrediti način razvitka duhovnosti odgojitelja u sustavu naprednog treninga. Metoda istraživanja: kulturozofijska, koja nam omogućuje pogled na duhovnost kao razvitak osjećaja za tu najvišu kulturnu vrijednost. Budući da je riječ o tehničkom sveučilištu, teorijski dio proučavanja uzima u obzir: multidimenzionalno poimanje duhovnosti; humanizaciju kao srž očitovanja »ljudskog duha« u odgoju, te humanitarizaciju kao put njegova iskazivanja; humanitarizaciju kao čimbenik u razvitku duhovnosti i strategiji pri oblikovanju i u razumijevanju značenja morala u inženjerskoj profesiji; humanitarnu okolinu (okružje) kao temelj duhovnog odgoja, morala i kulturnih osobnih svojstava; dijalog kao imperativ u razvitku duhovnosti. Praktičan dio rada opisuje rezultate autorova uvođenja novog programa s humanitarnom komponentom u Centru za napredne studije znanstvenih i pedagoških radnika Moskovskoga zrakoplovnog instituta (Nacionalnog istraživačkog sveučilišta): humanizacija i humanitarizacija stvaraju visoko duhovno okružje; tehnokratska ograničenost inženjerskog obrazovanja prevladava se interdisciplinarnošću; uočeno je povezivanje svih podsustava duhovnoga u društvu. Poteškoća u realizaciji programa bila je razlika u načinima mišljenja (tehničkog naprama humanitarnom) i u psihologiji nenaviknutoj na primanje informacije. Prevladavanje te spoznajne antinomije vodi dijalogu i razvija duh.

Ključne riječi: duhovnost, humanitarna okolina, humanizacija i humanitarizacija odgoja, interdisciplinarnost, kreativna narav odgoja, sustav naprednog treninga, tehnokratizam.

(s engl. prev. Josip Balabanić)

\footnotetext{
* Izv. prof. dr. sc. Svetlana A. Bezklubaya, Nacionalno istraživačko sveučilište, Institut za inženjerstvo, ekonomiju i humanističke znanosti Moskovskoga zrakoplovnog instituta, Odsjek za filozofiju; adresa: A-80, ГСП-3, 4 Volokolamskoe shosse, RU-125993 Moscow, Russia; e-mail: bezkluba@email.com.
} 